\title{
ANALISIS PROFIL KROMATOGRAFI LAPIS TIPIS DAN AKTIVITAS ANTIOKSIDAN METABOLIT SEKUNDER DARI EKSTRAK ETIL ASETAT HERBA KEROKOT (Lygodium microphyllum Cav. R. Br)
}

\author{
Nia Oktaviani", Wisnu Cahyo Prabowo, Laode Rijai \\ Laboratorium Penelitian dan Pengembangan Kefarmasian "Farmaka Tropis", \\ Fakultas Farmasi, Universitas Mulawarman, Samarinda \\ *Email : niaoktaviani31@rocketmail.com
}

\begin{abstract}
A research has been done to separation of compounds for ethyl acetate fraction with column vacum cromathography with concentration gradient started from nhexane:ethyl acetate (1:9) - ethyl acetate:methanol (1:9) resulted 14 fraction. Fraction 5,6 and 7 produced 2 spot with Rf spot A 0,95 and spot B 0,76. Spot B has antioxidant activity shown by the DPPH radical inhibition.
\end{abstract}

Keywords: Kerokot, Lygodium microphyllum, Antioxidant, DPPH, Column Vacuum Chromatography

\begin{abstract}
ABSTRAK
Telah dilakukan penelitian tentang pemisahan fraksi etil asetat menggunakan metode kromatografi kolom vakum dengan gradient konsentrasi dimulai dari perbandingan eluen n-heksan:etil asetat (1:9) - etil asetat:metanol (1:9) menghasilkan 14 fraksi. Fraksi 5, 6 dan 7 menghasilkan 2 noda dengan Rf noda A 0,95 dan noda B 0,76. Noda B mempunyai aktivitas antioksidan ditunjukkan dengan adanya inhibisi radikal DPPH.
\end{abstract}

Kata Kunci:Kerokot, Lygodium microphyllum, Antioksidan, DPPH, Kromatografi kolom vakum

\section{PENDAHULUAN}

Indonesia sebagai negara tropis memiliki beraneka ragam tumbuhan yang dapat dimanfaatkan sebanyak-banyaknya untuk kepentingan manusia. Masyarakat Indonesia sejak zaman dahulu telah mengenal tanaman yang mempunyai khasiat obat atau menyembuhkan berbagai macam penyakit. Tanaman tersebut dalam 
penggunaannya dikenal dengan obat tradisional. Popularitas dan perkembangan obat tradisional semakin meningkat seiring dengan slogan "kembali ke alam" dan kebutuhan obat baru dari sumber bahan alam maupun sintesis yang murah, berkhasiat dan terjamin ketersediannya. Secara empiris, herba tumbuhan kerokot (Lygodium microphyllum Cav. R. Br.) ini digunakan oleh masyarakat sebagai obat batuk dan demam. Sedangkan secara pendekatan taksonomi, spesies lain dari genus yang sama memiliki aktifitas sebagai antioksidan, antimikroba, antiviral, penumbuh rambut dan hepatoprotektor. Fraksi etil asetat herba kerokot memiliki IC50 antioksidan pada konsentrasi 17,39 ppm (Rahayu, 2012). Metabolit sekunder fraksi etil asetat tersebut mengandung senyawa flavonoid, tanin, fenol, steroid dan triterpenoid (Ermawatie, 2012).

Antioksidan merupakan senyawa yang dapat meredam dampak negatif radikal bebas. Radikal bebas berperan dalam terjadinya berbagai penyakit degeneratif, karena radikal bebas memiliki elektron yang tidak berpasangan pada orbit terluarnya sehingga bersifat reaktif untuk bereaksi dengan molekul lain. Radikal bebas dapat merusak makromolekul seperti lipid membran sel, DNA, dan protein sel (Valko, et al., 2006).

\section{METODE PENELITIAN}

\section{Bahan}

Bahan yang diteliti adalah simplisia herba kerokot. Pelarut yang digunakan untuk ekstraksi dan fraksinasi adalah metanol, n-heksan dan etil asetat. Pengujian aktivitas antioksidan menggunakan DPPH dan $\mathrm{H}_{2} \mathrm{SO}_{4} 10 \%$. Silika yang digunakan adalah silika gel $60^{\circledR}$ dan silica gel $60 \mathrm{H}^{\circledR}$.

\section{Alat}

Peralatan yang digunakan dalam penelitian ini antara lain bejana maserasi, rotary evaporator $\left(\mathrm{B}^{\prime} \mathrm{U}^{\prime} \mathrm{CHI}{ }^{\circledR}\right)$, corong pisah $\left(\mathrm{Pyrex}^{\circledR}\right)$, plat KLT GF 254, oven, pipa kapiler, chamber, mikropipet $100-1000 \mu \mathrm{L}$, kolom diameter $9 \mathrm{~cm}$, vakum (B’U'CHI ${ }^{\circledR}$ ), lampu UV portable (UVGL-55 Handheld $U V$ Lamp $^{\circledR}$ ), penyemprot

\section{Cara Kerja}

\section{Persiapan sampel}

Sampel herba kerokot diambil bagian batang dan daun dalam bentuk segar yang kemudian dicuci dengan air mengalir dan dilakukan sortasi basah. Selanjutnya sampel dikeringkan tanpa terkena sinar matahari langsung. Sampel yang telah kering (simplisia) dilakukan sortasi kering dan diblender hingga terbenetuk serbuk kasar simplisia herba kerokot.

\section{Ekstraksi}

Serbuk simplisia herba kerokot sebanyak $1,4 \mathrm{Kg}$ diekstraksi dengan metode maserasi menggunakan pelarut metanol. Proses ekstraksi dengan metode maserasi 
berlangsung selama 24 jam dan dilakukan remaserasi dengan pelarut yang sama hingga pelarut bening. Maserat kemudian dipekatkan menggunakan rotary evaporatordan dilanjutkan dengan pwmekatandenganwaterbath dan dikeringkan dengan desikator hingga diperoleh ekstrak metanol herba kerokot kering.

\section{Fraksinasi}

Proses fraksinasi dilakukan secara bertingkat dengan metode ekstraksi caircair menggunakan pelarut $\mathrm{n}$-heksan dan etil asetat. Proses fraksinasi dengan nheksan dilakukan hingga jernih kemudian dilanjutkan difraksinasi menggunakan etil asetat. Fraksi etil asetat inilah yang digunakan dalam pengujian. Selanjutnya dipekatkan dengan evaporator, dikeringkan diatas waterbath dan dimasukkan ke dalam desikator hingga diperoleh ekstrak etil asetat herba kerokot kering.

\section{Penentuan Eluen}

Ekstrak kental etil asetat herba kerokot dilakukan profiling pemisahan dan dilakukan metode kromatografi lapis tipis untuk mendapatkan perbandingan eluen dengan pemisahan yang terbaik. Ekstrak etil asetat dielusi dengan gabungan eluen n-heksan:etil asetat dan etil asetat:metanol dalam berbagai perbandingan. Hasil pemisahan KLT diamati secara visibel, sinar UV $254 \mathrm{~nm}$ dan $366 \mathrm{~nm}$. Dilakukan pengamatan KLT dengan pereaksi semprot $\mathrm{H}_{2} \mathrm{SO}_{4} 10 \%$ dan Sitroborat

\section{Kromatografi Kolom Vakum (KKV)}

Ekstrak etil asetat herba kerokot sebanyak 10 gram dibasahi sedikit dengan metanol dan dimasukkan sedikit demi sedikit silika gel 60 dengan perbandingsn silika:sampel (1:1).Kemudian dilakukan pengelusian dengan eluen yang terpilih secara gradien menggunakan campuran pelarut n-heksan, etil asetat dan metanol. Hasil KKV yang ditampung dipekatkan dengan evaporator dan dikeringkan diatas waterbath, kemudian dimasukkan ke dalam desikator

\section{Deteksi Senyawa Antioksidan}

Kromatogram hasil pemisahan KLT dilakukan pemeriksaan senyawa aktif antioksidan menggunakan penyemprot DPPH $(0,008 \%$ dalam metanol). Berkas noda yang menghasilkan perubahan warna menjadi putih pucat merupakan senyawa yang memiliki aktivitas antioksidan, sehingga dilanjutkan pemisahannya.

\section{HASIL DAN PEMBAHASAN}

Serbuk simplisia herba kerokot sebanyak 1,4 Kg diekstraksi dengan metode maserasi menghasilkan ekstrak kering sebanyak 213 gram. Fraksi etil asetat hasil fraksinasi sebanyak 10 gram. Hasil kromatografi fraksi etil asetat yang memiliki pemisahan yang baik adalah n-heksan:etil asetat (3:7). Perbandingan eluen yang diperoleh digunakan sebagai dasar pemisahan menggunakan kromatografi kolom vakum. Fraksi etil asetat yang diperoleh digunakan untuk penentuan eluen. 


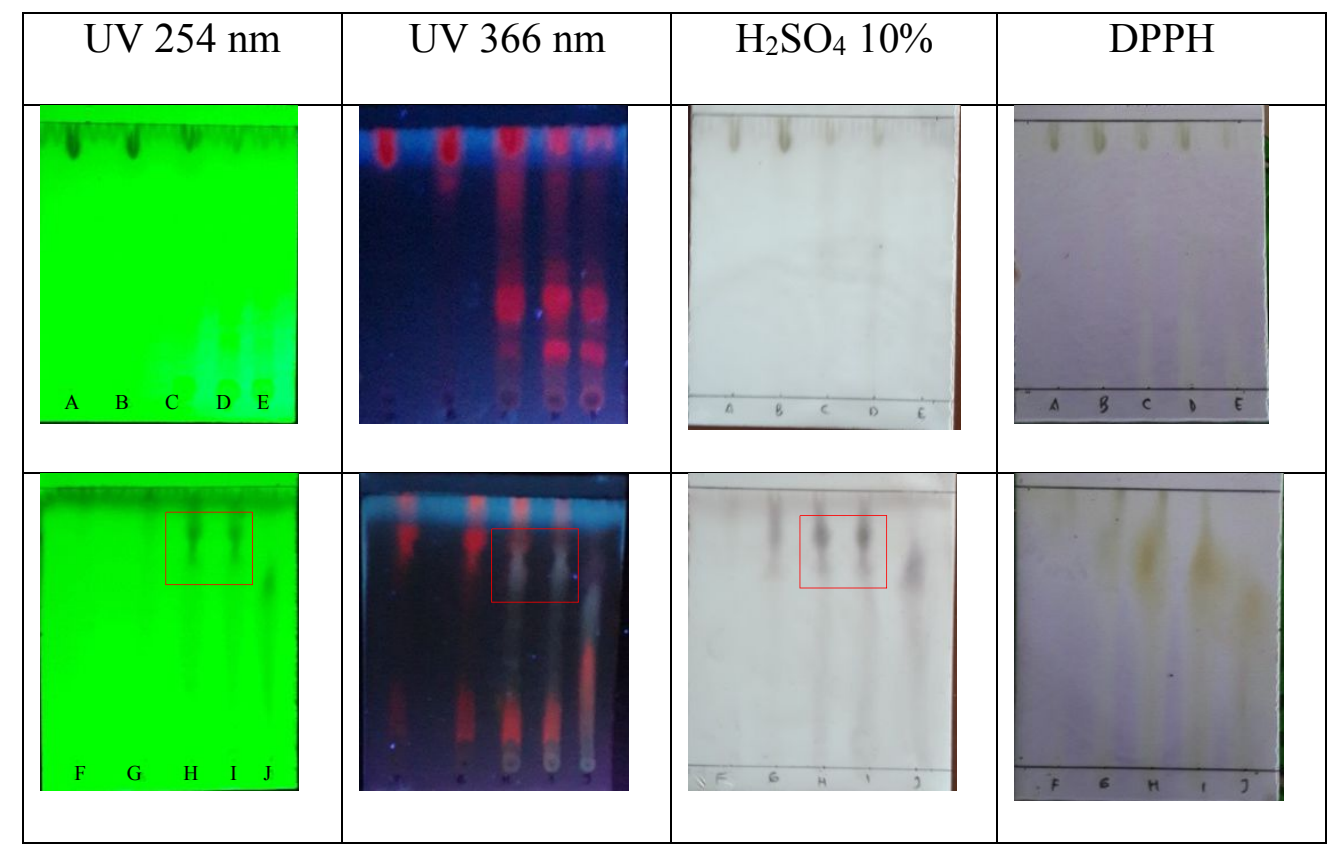

Gambar 1. Profil Kromatografi Kolom Vakum(I) dari Fraksi Etil Asetat Herba Kerokot. A-E (eluen n-heksan:etil asetat 2:8) F-J (eluen metanol:etil asetat 3:7) $\square$ : Fraksi yang memiliki aktivitas antioksidan

Fraksi etil asetat dielusi dengan berbagai perbandingan, dan diperoleh perbandingan eluen yang memiliki pemisahan yang baik adalah $n$-heksan:etil asetat (3:7). Perbandingan eluen yang diperoleh digunakan sebagai eluen pertama pada kromatografi kolom vakum untuk mengelusi ekstrak etil asetat. Ekstrak etil asetat dengan kromatografi kolom vakum menghasilkan 10 fraksi yang ditunjukkan profil kromatogramnya (Gambar 1). Sebanyak 3 gram fraksi H dan I yang digabungkan menunjukkan adanya aktivitas antioksidan yang ditandai dengan bercak kuning pada noda setelah disemprot dengan DPPH.

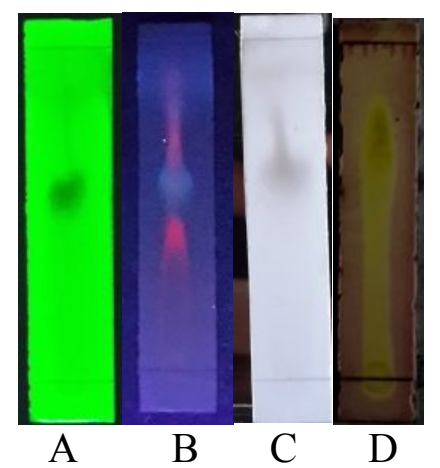

Gambar 2. Profil Kromatografi Lapis Tipis Fraksi HI (eluen metanol:etil asetat 1:9) A: UV 254 nm, B: UV 366 nm, C: $\mathrm{H}_{2} \mathrm{SO}_{4}$ 10\%, D: DPPH 
Analisis senyawa antioksidan pada fraksi HI dilakukan kembali penyemprotan DPPH, $\mathrm{H}_{2} \mathrm{SO}_{4} 10 \%$ dan Sitroborat(Gambar 2). Fraksi HI yang telah disemprot dengan DPPH yang menandakan adanya aktivitas antioksidan yang ditandai dengan bercak berwarna kuning pada noda dengan latar plat yang berwarna ungu. Fraksi HI masih menunjukkan noda yang belum tunggal oleh karena itu dilakukan kromatografi kolom vakum lagi untuk menghasilkan noda tunggal yang diinginkan.

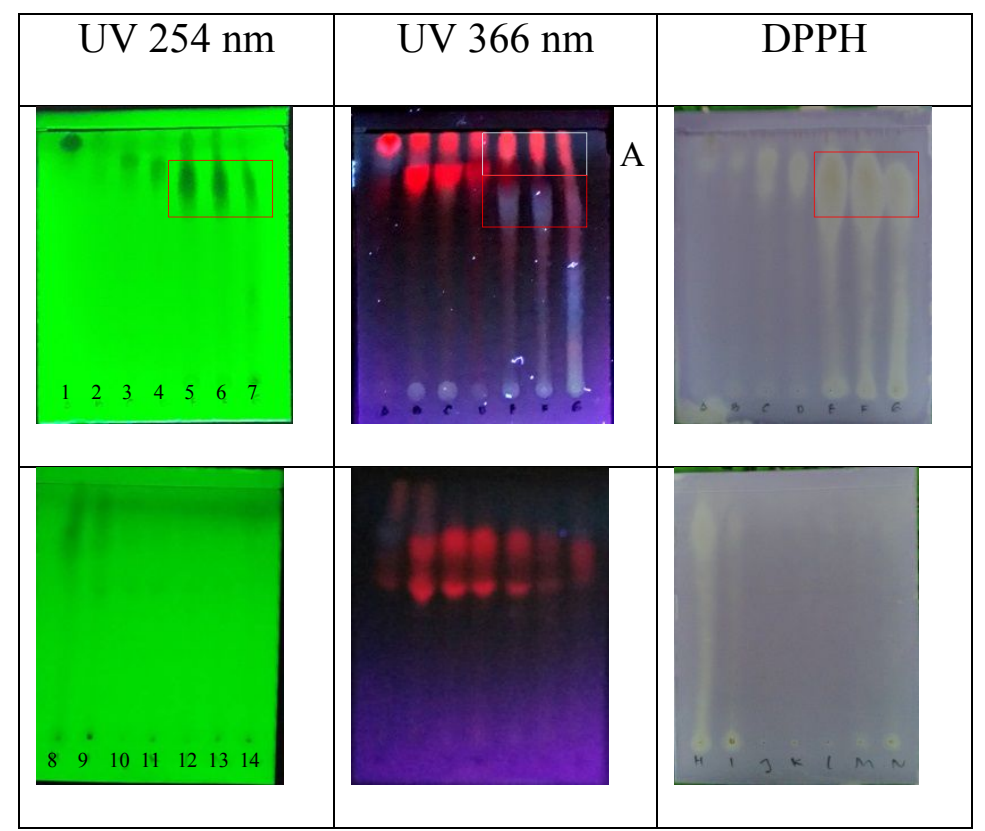

Gambar 3. Profil Kromatografi Kolom Vakum(II) dari Fraksi Etil Asetat Herba Kerokot. 1-7 (eluen etil asetat:metanol7:3) 8-14 (eluen etil asetat:metanol 3:7) $\square$ : Fraksi yang memiliki aktivitas antioksidan yang cukup baik

Fraksi HI dilanjutkan dengan pemisahan kembali menggunakan kromatografi kolom vakum, menghasilkan 14 fraksi (Gambar 3). Fraksi HI(5-7) menghasilkan 2 spot noda dengan Rf noda A 0,95 dan noda B 0,76. Noda B menunjukkan aktivitas antioksidan yang cukup baik.

\section{KESIMPULAN}

Berdasarkan hasil penelitian dapat disimpulkan bahwa:

1. Fraksi HI hasil kromatografi kolom vakum pertama dengan $\mathrm{Rf} 0,81$ pada hasil KLT menggunakan eluen metanol:etil asetat (1:9)

2. Fraksi HI (5-7) hasil kromatografi kolom vakum kedua memiliki aktivitas antioksidan pada noda B dengan Rf 0,76 menggunakan KLT dengan eluen metanol:etil asetat $(7: 3)$ 


\section{DAFTAR PUSTAKA}

[1] Ermawatie, Elly. 2012. Identifikasi Metabolit Sekunder dan Bioaktivitas Ekstrak Herba Kerokot (Lygodium microphyllum Cav. R. Br.)terhadap Artemia salina Leach. Skripsi. Fakultas Farmasi Universitas Mulawarman Samarinda

[2] Rahayu, Nanik. 2012. Aktivitas Antioksidan Ekstrak Herba Kerokot (Lygodium microphyllum Cav. R. Br.). Skripsi. Fakultas Farmasi Universitas Mulawarman Samarinda

[3] Valko, M. Et al. 2006. Free Radicals, Metals and Antioxidant in Oxidative Stress-induced Cancer. Chemico-Biological Interactions 160 (2006) 1-40, Elsevier: Ireland. 